\title{
上顎転移をみた肝細胞癌例
}

$\begin{array}{ll}\text { 福瀬 } & \text { 信也・牧本 一男・柴田伊十児 } \\ \text { 山本 } & \text { 祐三・高橋 宏明・芝山 雄老* }\end{array}$

\section{Metastatic Maxillary Tumor from a Primary Hepatic Cancer; A Case Report}

\author{
Shinya Fukuse, Kazuo Makimoto, Itoji Shibata, \\ Yuzo Yamamoto, Hiroaki Takahashi and \\ Yuro Shibayama
}

(Osaka Medical College)

An 81-year-old male complaining of nasal obstraction, epistaxis, and zygomatic swelling was admitted to Osaka Medical College Hospital. The histological diagnosis was metastatic maxillary tumor from a primary hepatocellular carcinoma. We employed intra-arterial infusion of ADM and BLM. These drugs were delivered through Tefron ${ }^{\circledR}$ catheters which were inserted into the right superficial temporal artery and hepatic artery. However, his general condition deteriorated gradually, and he died of hepatic failure. At autopsy, hepatocellular carcinoma was found to be of the massive type and Edmondson's type II and to coexist with Nagayo's type A cirrhosis. It had metastasized to the right maxillary sinus, lungs, and right adrenal gland. These metastases were considered to be hematogenous.

Key words: metastatic maxillary tumor, hepatocelluiar carcinoma, intra-artery infusion

はじめに

原発性肝癌の他臟器への転移は極めて高率で あるのにかかわらず，それが上顎に転移した報 告は非常に少ない，我々は鼻閉・鼻出血・顂部 腫脹を主訴とした患者で検査の結果, 肝細胞癌 の上顎転移と判明した症例を経験した。本症例 の臨床経過, 剖検所見について記述し, 若干の 文献的考察を加えて報告する.
症例

症例 : 81歳, 男性, 元公務員.

主訴：鼻閉および鼻出血.

既往歴: 数十年来, 胃潰瘍のために近医内科 に通院していた。また数年前に肝硬変を指摘さ れていた.

家族歴：特記すべき事項なし.

現病歴：昭和 62 年 9 月頃より鼻閉が続き, と 
きどき鼻出血をきたしたため近医耳鼻科受診し， 慢性副鼻腔炎の晾断のもとに通院治療を続けて いた。しかし改善傾向がみられなかったため， 同年 11 月 24 日に大阪医大耳鼻咽喉科を紹介さ れた。

初獄時所見：鼻内所見では，右鼻腔内は腫瘍 で充満し，下甲介は鼻中隔側に，また右口蓋は 下方に圧排されていた。副鼻腔断層撮影(困 1), CT (図 2) の結果, この腫瘍は, 上顎洞, 節骨

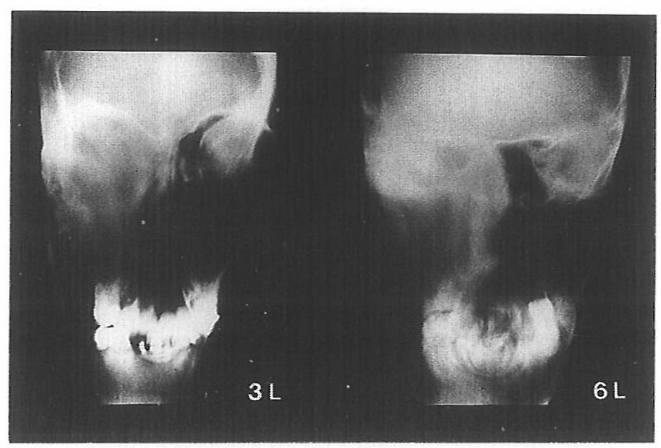

図1副鼻腔断層写真で, 上䪹洞および節骨洞に陰影 がみられ，右眼窩下壁の欠損がみられる。

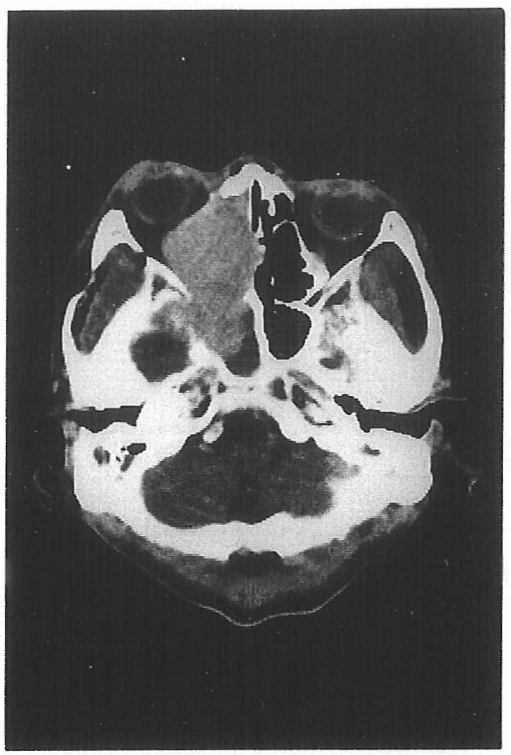

図 2 副鼻膑 CT スキャンで，上顎洞，穊骨洞，蝶形 洞に求よふ腫湯性病変を認め, それは鼻中隔を 圧迫している。
洞に主座を持ち，眼窩下壁および上顎洞前壁に は骨欠損が生じているのが認められた。全身所 見では黄疸や腹水などは認められなかったが， 腹壁静脈の怒脹が見られた。血液所見では， $\mathrm{HBs}$ 抗原 $2^{12}$, HBe 抗原 $(-), \mathrm{HBe}$ 抗体 $(+)$, $\mathrm{HBc}$ 抗体 $(+)$, 肝酵素の高值 (GOT 48U/137 ${ }^{\circ} \mathrm{C}$ ， GPT $63 \mathrm{U} / 137^{\circ} \mathrm{C}$ ) が見られた。 その他， ALP $374 \mathrm{U} / 137^{\circ} \mathrm{C}$, LDH $444 \mathrm{U} / 137^{\circ} \mathrm{C}$, T-Bil $0.8 \mathrm{mg} / \mathrm{dl}, \gamma-\mathrm{GTP} 188 \mathrm{U} / 137^{\circ} \mathrm{C}$, 血清蛋白分画 ではアルブミンの低下とガンマグロブミンの上 昇がみられた，止血機能は正常であった。軽度 の右煩部粘膜腫脹がみられ，検査所見より右上 須洞腫瘍と診断され，11月25日入院となった。

入院後経過（表 1 ）：11月 25 日鼻内腫瘍より 生検を行ったところ，採取部より噴出するよう な出血がみられた。鼻内生検の結果は hepatoma 様の構築を持つ adenocarcinoma と診断さ れた。 との間，腹部の膨満感をきたすようにな り，腹水の貯留が疑われたため，本学内科を受 診し，腹部エコーで肝癌が疑われた。 また $\mathrm{Ga}$ シンチで肝臟および右上顎洞に up take を認め, 血液所見では, CEA $1.3 \mathrm{ng} / \mathrm{ml}$ は正常であった が, AFP は $29 \mathrm{ng} / \mathrm{ml}$ と高值を示していた。 以 上の結果により, 肝細胞癌の転移性上顎癌であ るととが判明した，昭和63年 1 月 7 日に肝動脈 より肝動脈造影を行うとともにアドリアマイシ ン $40 \mathrm{mg}$ を動注した。造影では肝右葉全体に 広狭不整な異常血管を認め, 大小様々な腫瘍像 を認めた１月中旬よりアンチトロンビン III が 低下しはじめ，止血機能に異常がみられるよう になった。また AFP 值 $39 \mathrm{ng} / \mathrm{ml}$ と上昇して きた，肝硬変の合併もあり食道静脈瘤が高度と なってきたため，1月26日および2月 2 日に硬 化術を行った。2月17日から25日までに右浅側 頭動脈よりアドリアマイシン $10 \mathrm{mg}$ を 4 回, 合 計 $40 \mathrm{mg}$ の動注を行ったが效果はみられなかっ た. 3 月になると全身の衰弱が著しく中心静脈 栄養や輸血などにより改善をはかったが，その 効果もなく，3月14日死の転帰をとった，死後 直ちに病理解剖を行った。 
剖検所見 : 肝臓 $(1270 \mathrm{~g})$ は, 表面は凹凸不整 であった，肝細胞癌は肉眼的には塊状型を示し， 原発性肝癌取扱規約による組織学的分類では偽 腺管型で, Edmondson 分類では】型で, 胆汁産 生，細胞形質内封入体（球状硝子体）あみられ た（図 3 ）。癌は門脈右枝㧍よび下大静脈にま で浸潤增殖していた。また乙型肝硬変の合併が
認められた。

転移は, 肺 (図 4), 副腎および右側鼻副鼻 腔（図 5 ) にみられた。同部の癌の組織像は原 発巣と同一であった。

膵は, $140 \mathrm{~g}$ で高度の膵壊死がみられた. 食道 は硬化術後状態で, 静脈瘤は軽度であった。腹 腔内に腹水 $1900 \mathrm{ml}$ が貯留していた。

表 1

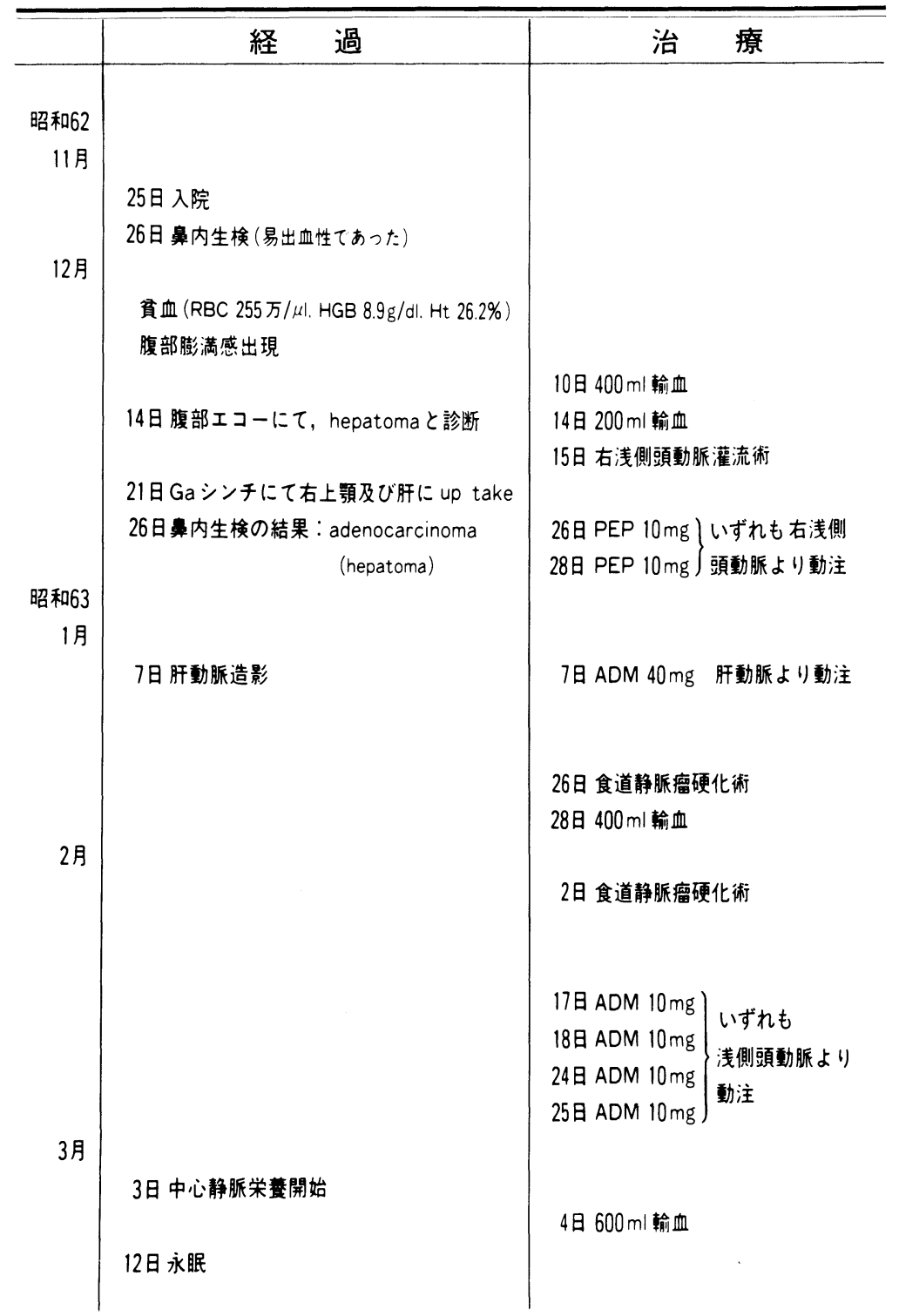




\section{考 按}

原発性肝癌の予後は不良で62～76\%が発見後 6 力月以内に死亡すると報告されている

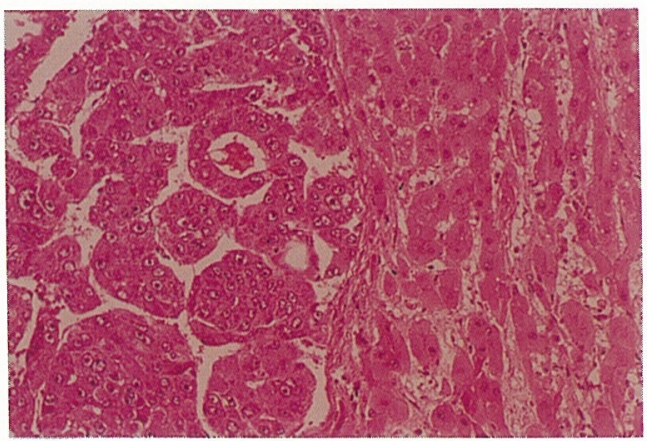

図 3 肝右葉の組織像を示す. 写真左半分は腫瘍病変 で癌は島状の蜂巣を形成して增殖しているのが 認められる. 右半分は非癌部である。

(H. E. 染色 200 倍)

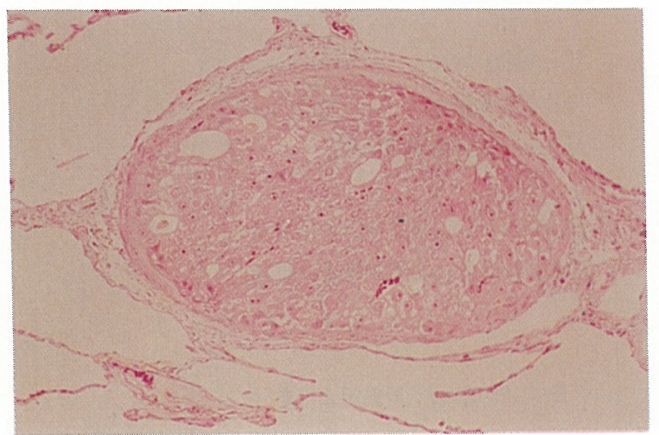

図 4 肺の転移病宩を示す，肺血管は肝細胞癌でほぼ 完全に充填されている. (H. E. 染色200倍)

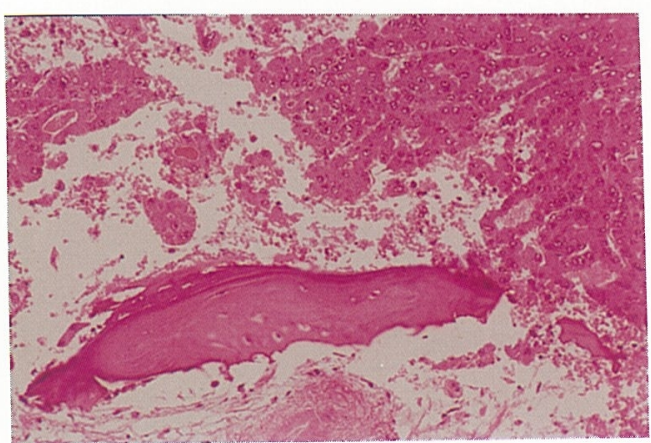

図 5 上顎洞に認められた腫瘍の組織像である。肝細 胞索を行彿させるような構築を持った肝細胞癌 が充実性に增殖している．下方には上顎骨骨片 が認められる. (H. A. 染色 200 倍)
れは進行した状態で発見される例が多いためと されているが，その理由として肝癌の初期には 肝機能に余力があるために肝機能障害が出現し にくいとと，また肝硬変を合併している例が多 いことなどにより，初期での発見は困難である と考えられている．また転移率が高いととあ予 後不良の大きな要因と考えられている。宮地ら は剖検検索例 442 例を検討した結果74. 4\% 亿転 移を認め，そのうち血行性が最も多く52.9\%を 占め, 次いでリンパ行性が $42 \%$, 直達性は, 27. 3\%の順であったと報告している ${ }^{1)}$. 臟器別 では表 2 に示すように，肺とリンパ節に高率に みられている.

本症例では，肺血管の一部に肝細胞癌が認め られたこと（図4）と，リンパ節に転移を認め られなかったととにより，上顎への転移は血行 性転移によるものであったと考えられる，すな わち転移経路としては閒脈，下大静脈，右心房， 右心室，肺，左心室，全身へという経路が考え られる。このように転移率の高い腫瘍に拘らず 原発性肝癌の上澦への転移は稀であり，しかも 今回のように固有鼻腔にもその病巣がみられた 例は極めて特異な例と考えられる。

眼窩内転移が先に発見される報告 ${ }^{3) ~ 6) ~ の 万 か ゙ ~}$ 上顎転移のそれて に比へて多い，乙の理由と して, 外頸動脈領域よりも内頸動脈領域に転 移発生をきたし易い傾向があるためと推察され る.それを裏づけるものとして表 2 にみれる ように大脳への転移は $0.1 〜 3.4 \%$ の率である と報告されている。一方では眼窩はその容量は 小さく骨壁に囲まれた円錐をなしているので, 一旦そこに転移した場合は，早期に眼球突出な どの症状が発現するととになる。乙れに比べ上 顎転移の場合は症状の発現が遅れることが考え られ，本症例においても転移巣が上顎洞，節骨 洞, 蝶形骨洞, 固有鼻腔にまで進展した段階で 上顎腫瘍と診断されている. 従って肝癌が進行 した状態にあっては，上顎転移による初期の症 状は見逃され，そのまま死の転帰を取る場合も 考えられる。 
原発性肝癌が転移巣の症状の発現をきっかけ として発見される割合は1.5〜 5. 3\%とされてい る(10)11)。乙れに関連して，宮地は診断的中率と して剖検記録によって臨床診断と剖検診断の対 比を試みたととろ，肝癌と正しく診断されてい る例は意外に少なく，その診断率は $45.6 \%$ であ り，他は肝硬変が $18.2 \%$, 腹部悪性腫瘍が 10.8 $\%$ ，胃癌 $7.0 \%$ ，気管支癌 $5.3 \%$ であった ${ }^{1}$. 現 在では肝ェコー, 腹部 $\mathrm{CT}$, 肝生検等により肝 癌の診断は非常に向上してきているので，転移 巣より原発性肝癌が発見される率は更に上昇す るものと考えられる．本症例においても，腹水 の出現があり，腹部エコーを行うことにより初
めて肝癌と診断されている.

肝癌の治療法には，外科的治療と化学療法が ある. 肝癌の外科的治療の適応 ${ }^{12)}$ となる割合は, 初期癌の発見が困難であるため少ない，化学療 法としては, FT-207 の経口投与や, mitomycin C, endoxan, methotrexate, vincristine が用いら れている。 またアドリアマイシンも延命効果を もとめて使用される例が多い13)。乙れら制癌剤 の治療には静脈内投与による全身投与と肝動脈 に直接注入する方法がある，肝癌に対する動注 療法は近年に進歩の著しい領域であり，肝動脈 よりの制癌剤の注入と塞栓とを組み合わせる， これよりまた制癌剂を徐放性の剂形に対する工

表 2

\begin{tabular}{|c|c|c|c|c|c|c|c|c|c|c|}
\hline 報 告者 & $\begin{array}{l}\text { 宮地ら } \\
\text { (1959) }\end{array}$ & $\begin{array}{c}\text { 森 } \\
(1956)\end{array}$ & $\begin{array}{l}\text { Shanmu- } \\
\text { garatnam } \\
(1956)\end{array}$ & $\begin{array}{c}\text { Lunze- } \\
\text { nauer } \\
(1955)\end{array}$ & $\begin{array}{l}\text { Köhn } \\
\text { (1955) }\end{array}$ & $\begin{array}{l}\text { Meyer } \\
\text { (1954) }\end{array}$ & $\begin{array}{c}\text { Edomond- } \\
\text { son- } \\
\text { Steiner } \\
\text { (1954) }\end{array}$ & $\begin{array}{c}\text { Rosen- } \\
\text { berg } \\
(1948)\end{array}$ & $\begin{array}{l}\text { Hoyne } \\
\text { (1947) }\end{array}$ & $\begin{array}{l}\text { Greene } \\
\text { (1936) }\end{array}$ \\
\hline 数 & 442 & 104 & 94 & 99 & 51 & 89 & 90 & 55 & 31 & 386 \\
\hline 転移頻度 $\%$ & 74.4 & 71.1 & - & 76.7 & 75.0 & 51.6 & 46.6 & 72.7 & 67.7 & 31 \\
\hline 肺 & 43.2 & 46.1 & 31.0 & 37.0 & 20.0 & 21.3 & 59.1 & 67.5 & 41.0 & 28 \\
\hline 腎 & 7.4 & 3.8 & 2.1 & 7.7 & & 5.5 & 0 & 5.0 & & \\
\hline 骨・骨 髄 & 7.2 & 4.8 & 2.1 & 15.0 & 18.0 & 13.4 & 8.3 & 5.0 & 9.6 & 8 \\
\hline 副腎 & 6.7 & 5.7 & & 7.1 & & 5.6 & 8.3 & 7.5 & 16.1 & 3 \\
\hline 脾 & 4.7 & 4.8 & & 7.1 & 3.0 & & 5.5 & 2.5 & 6.4 & \\
\hline 胃 & 5.5 & 3.8 & 3.2 & & & & 0 & & 3.2 & \\
\hline 膵 & 3.1 & 4.8 & 2.1 & 4.0 & & & 2.7 & 2.5 & 9.6 & \\
\hline 大 脸 & 1.0 & & & 3.0 & & 3.4 & & & & \\
\hline リンパ節 & 42.0 & & 15.6 & & & & & & 36.8 & \\
\hline 肝 門 部 & 15.1 & 15.3 & & 25.2 & & 25.8 & 38.8 & 67.5 & & 18 \\
\hline 後 腹 膜 & 12.2 & 11.5 & & & & & 11.1 & & & \\
\hline 膵 周 囲 & 8.6 & 5.7 & & & & 13.4 & 5.5 & & & \\
\hline 腸 間 膜 & 8.6 & 1.9 & & & & & 0 & & & 5 \\
\hline 胃 周 囲 & 9.6 & 6.7 & & & & 1.1 & & 2.5 & & \\
\hline 肺 門 部 & 6.5 & 6.7 & & & & & & & 19.3 & \\
\hline 傍気管支 & 5.2 & 3.8 & & & & & 2.7 & & & \\
\hline $\begin{array}{l}\text { 傍大動脈 } \\
\text { 直 達 性 }\end{array}$ & 4.3 & & & & & 11.2 & 8.3 & & & \\
\hline 横 隔 膜 & 6.7 & 12.5 & 10.6 & & & & 16.6 & 12.5 & 12.9 & \\
\hline 胆 & 7.2 & 5.7 & & 5.0 & & 5.6 & 2.7 & 7.5 & 6.4 & \\
\hline 大 & 6.1 & 5.7 & & & & & 0 & 15.0 & 0.9 & \\
\hline 腹 & 6.1 & 19.2 & 2.1 & & & 5.6 & 11.1 & 13.5 & 9.6 & \\
\hline 助 & 4.9 & & & & & & & 7.5 & & \\
\hline 膵 表 面 & 2.9 & 4.8 & & & & & 2.7 & & 9.7 & \\
\hline
\end{tabular}


夫などにより，腫瘍縮小効果に改善がみられて いる. 動注療法の利点は投与量が少量で効果が 得られるととで, 白血球减少, 血小板減少など の副作用が少ない．本症例においてもアドリア マイシンによる動注療法を行ったが高齢で既に 全身的衰弱が高度であったため，回数を重ねて 施行することはできなかった。

我々は今回の症例を経験した教訓として，副 鼻腔悪性腫瘍をみた場合必ず全身他部位への転 移，またはその逆の場合を考えて $\mathrm{Ga}$ シンチを 施行するととが重要であると痛感した。また頭 頸部腫瘍と肝硬変の合併がある場合は, 治療前 に AFP などの肝癌に対する腫瘍マーカーを測 定し，もし高值を示す場合は肝癌の合併も念頭 に置き，侵襲がなくしか屯診断能力の優れた腹 部エコーを積極的に行う必要があるものと考 えた。

\section{まとめ}

原発性肝癌の右上顎転移を来した81歳男性の 一例を報告した。本症例は，鼻閉，鼻出血，頓 部腫脹などのため上顎洞腫瘍之診断され，その 生検により原発性肝癌の上顎転移であることが 判明した。治療は，アドリアマイシンの肝動脈 及び浅側頭動脈への動注を行ったが短期間に全 身状態が悪化し死の転帰を取った，剖検では原 発性肝癌は肝細胞癌で, 肉眼的には塊状型で, 組織学的分類は偽腺管型であった。また乙型肝 硬変の合併が認められた。転移は, 右上顎の他, 肺, 副腎に認められ, 血行性転移と考えられ た．頭頸部腫瘍で肝硬変の合併があるときには AFP の測定や腹部エコーなどで肝癌の有無に 注意する必要があると考えた。

\section{参考文献}

1) 宮地 徹, 游 鴻儒, 小田富雄, 他: 最近10年間 におけるわが国の原発性肝癌 (病理学的研究).
肝臟 $1: 1 ; 17 \sim 36,1960$.

2) 森亘：ヘパトームについて一剖検者の眺めた 臨床症状. 総合臨床 $11: 2045 \sim 2058 ， 1956$.

3 ) 今井 亮: 肝臓二原発セル転移性眼窩癌腫ニツイ テ. 日眼 $45: 353,1941$.

4 ) 田中耕一, 大迫茂人, 黒木哲夫, 他 : 眼球突出を 主訴とした原発性肝癌の一剖検例. 耳鼻臨床 71 增 $1: 655 \sim 660,1978$.

5 ) 後藤まゆき, 加納直行, 牧本一男, 他: 肝細胞癌 の眼窩内転移の一例. 耳鼻臨床 $79: 253 \sim 257$, 1986.

6 ）原田邦子, 杜若陽祐, 杜若幸子, 他：遠隔転移条 から発見された肝細胞癌. 臨放 $32 ： 1581 １ 584$, 1987.

7 ）岩武博也, 堤康一朗, 渡来潤次, 他 : 穊骨洞転移 により判明した肝細胞癌の一症例. 耳鼻臨床 補 $9: 121 \sim 126,1987$.

8 ）小林秀夫：上顎洞に軽移せるヘパトームの稀有な る一例. 日耳鼻 $54: 184 \sim 187,1951$.

9) Nishioka K, Ishihara M, Kimura M, et al : Hepatoma metastasizing to the retromaxillary region with initial otologic manifestation. Hiroshima J Med Sci $32:$ 407 411, 1983.

10) Edmondson HA and Steiner PE : Primary carcinoma of the liver; a study of 100 cases among 48900 necropsies. Cancer $7: 462 \sim 503,1954$.

11) Berman C : Primary carcinoma of the liver. A study in incidence, clinical manifestation. Pathology and Aetiology. Lewins, London, 1951.

12）本庄一夫, 土屋涼一：肝癌の外科的治療. 日本臨 床 $25: 2353 \sim 2359,1967$.

13）大村孝志, 佐藤和宏, 五十風究, 他 : 原発性肝癌 の遠隔転移に関する検討. 日臨外医会誌 $45: 6$; 793, 1984.

\footnotetext{
$\left(\begin{array}{l}\text { 原稿受付 : 平成元年 } 9 \text { 月 } 21 \text { 日 } \\ \text { 原稿採択 : 平成元年 } 10 \text { 月 } 30 \text { 日 } \\ \text { 別刷請求先 : 福瀬信也 } \\ \text { T569 高梘市大学町 } 2-7 \\ \text { 大阪医科大学耳鼻咽喉科学教室 }\end{array}\right)$
} 